\title{
JOURNAL OF BIOMEDICAL RESEARCH AND CLINICAL PRACTICE
}

\section{Original Article}

\section{Pattern of Ocular and Adnexal Injuries Requiring Surgical Intervention among Children in a Tertiary Center in North-Central Nigeria: A 14 Year Review}

Odugbo OP.*, Wade PD., Ewuga RO., Mpyet CD.

Department of Ophthalmology, Faculty of Clinical Sciences, College of Health Sciences, University of Jos, P.M.B. 2084, Jos-Nigeria

\section{ABSTRACT}

*Corresponding Author: Dr OP Odugbo, Department of Ophthalmology, Faculty of Clinical Sciences, College of Health Sciences, University of Jos, P.M.B. 2084, Jos-Nigeria. Email: odugp@yahoo.com

The study assessed the pattern of ocular and adnexal injuries that required surgical intervention among children with the aim of strengthening preventive, curative and promotive eye care services.The ophthalmic surgical database of the facility was retrospectively reviewed to obtain information on children who had surgical intervention due to trauma from 1st January 200431st December 2017; these included demographic data; diagnosis, procedure and the type of anaesthesia administered. Epi Info software, version 3.4 was used for analysis. A total of 361 children (aged <18years) underwent a surgical procedure as a result of ocular trauma within the stated period. There were more males $255(70.6 \%)$ than females $106(29.4 \%)$ with a male:female ratio of 2.4:1. The mean age was 7.7 \pm 3.5 years, 356(98.6\%) participants had general anaesthesia administered, 267(73.9\%) were aged $\leq 10$ years. The main indications for surgical intervention were corneal laceration 143(39.6\%), traumatic cataract 99(27.4\%), corneo-scleral laceration 34(9.4\%), lid \pm canalicular laceration 21 (5.8\%), intraocular foreign body 16(4.4\%), ruptured globe $14(3.9 \%)$ and limbal rupture 11(3.1\%). A higher proportion of males had corneal laceration 104(40.8\%, $\mathrm{p}=0.40)$, intraocular foreign body $13(5.1 \%, \mathrm{p}=0.25)$ and ruptured globe $12(4.7 \%, \mathrm{p}=0.17)$ while a higher proportion of females had traumatic cataract $35(33 \%, \mathrm{p}=0.14)$, lid laceration $4(3.8 \%, \mathrm{p}=0.76)$ and scleral laceration $2(2.8 \%, \mathrm{p}=0.33)$. The observed differences were however not statistically significant. Of 21 participants who had lid injuries $14(66.7 \%)$ were aged $\leq 5$ years. Of 14 participants who had ruptured globe, $8(57.1 \%)$ were aged 11-17years. We observed that a male child is twice more likely to have an ophthalmic surgery due to trauma.

Keywords: Adnexa, Ocular, Paediatric, Surgery, Trauma.

\section{INTRODUCTION}

Trauma can be defined as "bodily lesion at the organic level, resulting from acute exposure to energy (mechanical, thermal, electrical, chemical or radiant) in amounts that exceed the threshold of physiological tolerance". ${ }^{1}$ Eighteen million people worldwide have uniocular blindness from traumatic injury. Injuries are disproportionally more common in childhood. ${ }^{2}$ Eye trauma is the most common cause of unilateral blindness in
2018 Joumal ImpactFactor: 1.10 PintISSN:2636-7378|OnlineISSN:2651-5865

children. ${ }^{2}$ The number of serious eye injuries in children has been estimated at 11.8 per 100,000 per year, at least $35 \%$ of all serious eye injuries occur in children. ${ }^{2-3}$ Ocular adnexal injuries that could necessitate surgical intervention include laceration of the eyelid, conjunctival and lacrimal drainage system. Ocular trauma can be broadly classified into two. 'Closed globe' and 'open globe' injuries. Ocular injury that occurs when there is 
no full thickness wound of the cornea and sclera is termed "closed globe injury ${ }^{4}$, while open globe injury refers to ocular injury which occurs when there is a full thickness wound of the cornea/sclera. ${ }^{5}$ Closed globe injuries comprise contusive and lamellar lacerations while open globe injuries comprise laceration and rupture. Globe laceration can be further subdivided into penetrating injuries, perforating injuries and injuries with retained intraocular foreign bodies. A laceration of the globe that has only an entry point is referred to as "a penetrating injury". The causative agent enters the eye but does not pass all the way through. ${ }^{5}$ When there are two full thickness lacerations (an entry point and an exit point) caused by the same offending agent, it is termed a perforating ocular injury. ${ }^{4}$ In simple lacerations, the eye is injured with a sharp object. Virtually any object imaginable has been responsible at one time or another for an ocular laceration. Very young children usually suffer ocular injury when they fall on sharp objects, such as pencil, nail or toothpick. Older children may suffer eye wall lacerations from glass (particularly when they wear spectacles) and projectiles. ${ }^{5-7}$ Bottle rockets and knives are other common causes. Unusual causes include the peck of a chicken which carries the risk of endophthalmitis caused by unusual bacterial species from the bird's beak.

When a globe is ruptured, it is pushed or squeezed so hard that the coats of the eye break under pressure. The results are usually devastating, with partial or complete expulsion of intraocular contents. Expulsion is facilitated due to the increase intraocular pressure followed by a sudden decompression through a hole in the wall of the eye. Events that can cause ruptured globes include encounters with large, usually blunt, objects. A fist fight can result in a ruptured globe, as can injury from the force of a small projectile, such as a handball, squash ball, racquetball or baseball. Eyes are more likely to be ruptured or lacerated in areas where the sclera or corneal are thinnest. The areas under the insertions of the recti and superior oblique muscles and also the corneo-scleral limbus are thin and more likely to give way under pressure. Globe lacerations could be anterior or posterior. Anterior locations of injuries generally carry a better prognosis. Injuries anterior to the pars plana (located approximately $5 \mathrm{~mm}$ posterior to the limbus) will not cut the retina and therefore carry a better prognosis. ${ }^{6}$ Posterior injuries cut the retina and often result in a complicated retinal detachment. Although these retinal detachments may be amenable to treatment, they carry a far worse prognosis than if the laceration were anterior.
The diagnosis of penetrating eye injury is obvious when a laceration is apparent. Clues to occult penetration include subconjunctival haemorrhage, distorted pupil, wrinkled lens capsule and lowered intraocular pressure, particularly compared to pressure in the fellow, uninjured eye. The child's or family's history may or may not corroborate the physical findings.

Closed globe injuries that may necessitate surgical intervention include traumatic hyphaema and traumatic cataract. Traumatic cataracts can occur either as a result of a sharp penetrating injury to the lens or a blunt concussive force. ${ }^{7}$ Traumatic cataracts may occur immediately after the injury, or may occur days to even years after a concussive blow. So long as the child is beyond the age when amblyopia can develop, the initial repair of a corneal or scleral laceration can be followed at a later date with the removal of the lens if the anterior capsule is intact. This 'wait-and-see' strategy has no deleterious effects on the child other than the necessity for a second general anaesthetic.

\section{Aim}

To assess the pattern of ocular and adnexal injuries that required surgical intervention among children for the purpose of further strengthening preventive, curative and promotive eye care services.

\section{MATERIALS AND METHODS}

The ophthalmic surgical database of our eye care facility was retrospectively reviewed to obtain information on children who had surgical intervention due to trauma from 1st January 200431st December 2017. These included demographic data; preoperative diagnosis, surgical procedure, type of anaesthesia administered and the rank of surgeon. The data was entered into Epi Info statistical software, version 3.4 and analyzed after validation by double entry. Descriptive statistics was used to yield frequencies, percentages and proportions. Analytical statistics was applied and a $\mathrm{p}$ value $<0.05$ was considered statistically significant. Ethical approval was obtained from the Institutional Medical Research Ethics Committee.

\section{RESULTS}

A total of 361 children (aged < 18years) underwent a surgical procedure as a result of ocular trauma within the stated period. There were more males 255(70.6\%) than females 106(29.4\%) 
with a male:female ratio of 2.4:1(Table 1). The observed difference in the distribution of participants by gender was statistically significant $(\chi 2=122.8, p<0.001)$. The mean age was $7.7 \pm 3.5$ years. Table 1 also revealed the highest proportion of participants $147(40.7 \%)$ were aged 6-10 years, and 267(73.9\%) were aged $\leq 10$ years.

Table 1: Age -sex distribution of children with ocular injuries that required surgical intervention

\begin{tabular}{lllllll}
\hline $\begin{array}{l}\text { Age Group } \\
\text { (years) }\end{array}$ & Male & \multicolumn{3}{c}{ Female } & \multicolumn{2}{c}{ Total } \\
No & \% & No & \% & No & \% \\
\hline$<\mathbf{1}$ & 6 & 2.4 & 1 & 0.9 & 7 & 1.9 \\
$\mathbf{1 - 5}$ & 72 & 28.2 & 41 & 38.6 & 113 & 31.3 \\
$\mathbf{6 - 1 0}$ & 102 & 40.0 & 45 & 42.5 & 147 & 40.7 \\
$\mathbf{1 1 - 1 5}$ & 64 & 25.1 & 15 & 14.2 & 79 & 21.9 \\
$\mathbf{1 6 - 1 7}$ & 11 & 4.3 & 4 & 3.8 & 15 & 4.2 \\
\hline Total & $\mathbf{2 5 5}$ & $\mathbf{1 0 0}$ & $\mathbf{1 0 6}$ & $\mathbf{1 0 0}$ & $\mathbf{3 6 1}$ & $\mathbf{1 0 0}$ \\
\hline
\end{tabular}

Up to $356(98.6 \%)$ persons had general anaesthesia administered while only 5(1.4\%) had local anaesthesia administered $(\chi 2=682.6, \mathrm{p}<0.001)$. A significantly higher proportion $298(82.5 \%)$ of children had their procedure performed by an ophthalmologist-in training while 63(17.5\%) had it done by a consultant ophthalmic surgeon $(\chi 2=591.2$, $\mathrm{p}<0.001)$. The main indications for surgical intervention were corneal laceration 143(39.6\%), traumatic cataract 99(27.4\%), corneo-scleral laceration $34(9.4 \%)$, lid \pm canalicular laceration $21(5.8 \%)$, intraocular foreign body $16(4.4 \%)$, ruptured globe
14(3.9\%) and limbal rupture 11(3.1\%). Lacerations involving the outer fibrous coat of the eye were an indication for surgery in 204(56.5\%) participants while traumatic cataract (with and without comorbidity) was an indication in 105(29\%) persons. Table 2 revealed a higher proportion of males had corneal laceration 104(40.8\%), intraocular foreign body 13(5.1\%) and ruptured globe $12(4.7 \%)$. A higher proportion of females had traumatic cataract $35(33 \%)$, lid laceration $4(3.8 \%)$ and scleral laceration 2(2.8\%). None of the observed differences between males and females was statistically significant. A total of 2 children sustained injuries to both eyes thus 363 eyes were operated. A seven year old male child had both eyes mutilated in an attempt to remove his eyes for ritual practice; another child had bilateral lid laceration. A total of 372 procedures were performed on 363 eyes of 361 children, 9 eyes had more than 1 procedure. The most common surgical procedures were corneal repair $152(41.0 \%)$, cataract extraction/lens washout 105(28.3\%), corneo-scleral repair $34(9.2 \%)$ and lid \pm canalicular repair $25(6.7 \%)$. Procedures on the outer fibrous coat of the eyes (limbal repair, corneal repair, corneo-scleral repair and scleral repair) accounted for 204(54.8\%) of all procedures (Table 4).

Of 21 participants who had lid \pm canalicular injury 14(66.7\%) were aged $\leq 5$ years. And of 14 participants who had ruptured globe, $8(57.1 \%$ ) were aged 11-17years (Table 3).

Table 2: Distribution of type of ocular injury by gender

\begin{tabular}{|c|c|c|c|c|c|c|c|}
\hline \multirow[t]{2}{*}{ Type of ocular trauma } & \multicolumn{2}{|c|}{ Male } & \multicolumn{2}{|c|}{ Female } & \multicolumn{2}{|c|}{ Total } & \multirow[t]{2}{*}{ *Test statistic/ p value } \\
\hline & Freq & $\%$ & Freq & $\%$ & Freq & $\%$ & \\
\hline Foreign body on the eyelid & 1 & 0.4 & 0 & 0 & 1 & 0.3 & $0.4, p=0.52$ \\
\hline Lid \pm canalicular laceration & 14 & 5.4 & 7 & 6.6 & 21 & 5.8 & $0.15, p=0.76$ \\
\hline Limbal rupture & 7 & 2.7 & 4 & 3.8 & 11 & 3.1 & $0.31, p=0.61$ \\
\hline Corneal laceration & 104 & 40.8 & 39 & 36.8 & 143 & 39.6 & $0.53, \mathrm{p}=0.40$ \\
\hline Corneo-scleral laceration & 23 & 9.0 & 11 & 10.4 & 34 & 9.4 & $0.15, p=0.58$ \\
\hline Scleral laceration & 4 & 1.6 & 3 & 2.8 & 7 & 1.9 & $0.61, p=0.33$ \\
\hline Corneal and lid lacerations & 2 & 0.8 & 1 & 0.9 & 3 & 0.8 & $0.02, p=0.64$ \\
\hline Corneal laceration and traumatic cataract & 5 & 2.0 & 1 & 0.9 & 6 & 1.7 & $0.56, \mathrm{p}=0.41$ \\
\hline Traumatic hyphaema & 5 & 2.0 & 0 & 0 & 5 & 1.4 & $2.12, \mathrm{p}=0.17$ \\
\hline Traumatic cataract & 64 & 25.1 & 35 & 33.0 & 99 & 27.4 & $2.4, p=0.14$ \\
\hline Intraocular Foreign body & 13 & 5.1 & 3 & 2.8 & 16 & 4.4 & $0.95, \mathrm{p}=0.25$ \\
\hline Ruptured globe & 12 & 4.7 & 2 & 1.9 & 14 & 3.9 & $1.66, \mathrm{p}=0.17$ \\
\hline Orbital FB & 1 & 0.4 & 0 & 0 & 1 & 0.3 & $0.4, p=0.52$ \\
\hline Total & 255 & 100 & 106 & 100 & 361 & 100 & \\
\hline
\end{tabular}

*Chi Square test/Fischer's exact test 
Table 3: Distribution of type of ocular trauma by age group

\begin{tabular}{|c|c|c|c|c|c|c|c|c|c|c|c|c|}
\hline $\begin{array}{l}\text { Age } \\
\text { group }\end{array}$ & $\begin{array}{l}\text { FB on the } \\
\text { eyelid, } \\
\text { Globe \& } \\
\text { orbit }\end{array}$ & $\begin{array}{l}\text { Lid } \pm \\
\text { canalicular } \\
\text { laceration }\end{array}$ & $\begin{array}{l}\text { Limbal } \\
\text { rupture }\end{array}$ & $\begin{array}{l}\text { Corneal } \\
\text { laceration }\end{array}$ & $\begin{array}{l}\text { Corneo } \\
\text { scleral } \\
\text { laceration }\end{array}$ & $\begin{array}{l}\text { Scleral } \\
\text { laceration }\end{array}$ & $\begin{array}{l}\text { Corneal and } \\
\text { lid laceration }\end{array}$ & $\begin{array}{l}\text { Corneal } \\
\text { laceration \& } \\
\text { traumatic } \\
\text { cataract }\end{array}$ & $\begin{array}{l}\text { Traumatic } \\
\text { hyphaema }\end{array}$ & $\begin{array}{l}\text { Traumatic } \\
\text { cataract }\end{array}$ & $\begin{array}{l}\text { Ruptured } \\
\text { globe }\end{array}$ & Total \\
\hline$<1$ & $1(5.5)$ & $1(4.8)$ & $0(0)$ & $2(1.4)$ & $1(2.9)$ & $1(14.3)$ & $0(0)$ & $0(0)$ & $0(0)$ & $1(1.0)$ & $0(0)$ & $7(1.9)$ \\
\hline $1-5$ & $7(38.9)$ & $13(61.9)$ & $2(18.2)$ & $52(36.3)$ & $11(32.4)$ & $1(14.3)$ & $2(66.7)$ & $3(50.0)$ & $2(40)$ & $19(19.2)$ & $1(7.1)$ & $113(31.3)$ \\
\hline $6-10$ & $6(33.3)$ & $2(9.5)$ & $6(54.5)$ & $58(40.6)$ & $13(38.2)$ & $4(57.1)$ & $1(33.3)$ & $1(16.7)$ & $2(40)$ & $49(49.5)$ & $5(35.7)$ & $147(40.7)$ \\
\hline $11-15$ & $3(16.7)$ & $4(19.0)$ & $3(27.3)$ & $29(20.3)$ & $7(20.6)$ & $0(0)$ & $0(0)$ & $2(33.3)$ & $1(20)$ & $24(24.2)$ & $6(42.9)$ & $79(21.9)$ \\
\hline $16-17$ & $1(5.6)$ & $1(4.8)$ & $0(0)$ & $2(1.4)$ & $2(5.9)$ & $1(14.3)$ & $0(0)$ & $0(0)$ & $0(0)$ & $6(6.1)$ & $2(14.3)$ & $15(4.2)$ \\
\hline Total & $18(100)$ & 21(100) & 11(100) & $143(100)$ & 34(100) & $7(100)$ & $3(100)$ & $6(100)$ & $5(100)$ & 99(100) & $14(100)$ & $361(100)$ \\
\hline
\end{tabular}

Table 4: Distribution of types of surgical procedures

\begin{tabular}{l|l|l|l}
\hline S/no & Type of surgery & No & \% \\
\hline 1 & Foreign body removal & 18 & 4.8 \\
& from/eyelid/globe/orbit & & \\
2 & Lid \pm canalicular repair & 25 & 6.7 \\
3 & Limbal repair & 11 & 3.0 \\
4 & Corneal repair & 152 & 40.9 \\
5 & Corneo-scleral repair & 34 & 9.1 \\
6 & Scleral repair \pm cryotherapy & 7 & 1.9 \\
7 & Anterior chamber paracentesis & 5 & 1.3 \\
8 & Cataract extraction/lens washout & 105 & 28.2 \\
9 & Evisceration & 15 & 4.0 \\
\hline & Total & $\mathbf{3 7 2}$ & $\mathbf{1 0 0}$ \\
\hline
\end{tabular}

\section{DISCUSSION}

Generally speaking, children are more prone to severe ocular injuries due to their immature motor skills and their tendency to imitate adult behavior without anticipating the attendant risks coupled with ignorance and natural curiosity. The relative inability of younger children to detect and avoid hazards is also contributory. ${ }^{8-9}$ This study revealed that over two-thirds $(70.6 \%)$ of participants were males. This is comparable to related studies in Nigeria which showed a range of $63 \%-72.2 \% .^{10-}$

${ }^{16}$ This preponderance of the male gender is also in consonance with global findings that males (even in the pediatric age group) are more prone to ocular injuries compared with females with proportions ranging from $60 \%$ to over $70 \%$ reported in literature. ${ }^{17-23}$ We observed that a male child is twice more likely to have an ophthalmic surgical intervention due to trauma compared to a female child. In our setting, boys are generally allowed more liberty than girls and tend to spend more time outside with their peers, with less parental supervision. Boys are allowed and even encouraged to exhibit more aggressive behavior as part of their normal development. $24-25$

The mean age of this study group ( $7.7 \pm 3.5$ years) is also comparable to 7.73 years reported by Kyari et al. but lower than 8.7 years and 9.7 years reported by Adio et al. ${ }^{12}$ and Ojabo et al. ${ }^{10}$ respectively. The composition of the study population may be responsible for the difference in the mean age. We observed that close to three quarters $(73.9 \%)$ of participants were aged $\leq 10$ years. This is in agreement with report of studies in both developing and developed countries that the majority of eye injuries occur in children under the age of 12 years. ${ }^{8,9,26-29}$ Lacerations involving the outer fibrous coat (a total of 56.5\%) and traumatic cataract (a total of 29\%) were the most common ocular injuries that required surgical intervention. This is similar to findings by Adio et al. Okeigbmen et al., Ojabo et al., and Kyari et al., ${ }^{10-12,14}$ Up to $3.9 \%$ of participants had ruptured globe. This is less than $10.3 \%$ reported by Ojabo et al., in Makurdi, $5.1 \%$ reported by Kyari et al., in Kaduna and but higher than $1.9 \%$ reported by Okeigbemen in Benin City all in Nigeria. ${ }^{10,11,14}$

When the intraocular contents are affected, ocular trauma carries a poor prognosis. ${ }^{30-31}$ Once a laceration or globe rupture is diagnosed, emergency surgery is indicated, but the patient's overall health status should not be ignored. The eye laceration may accompany head trauma or other injuries. The main goal of surgery is repair of the laceration. With anterior lacerations, prompt closure and re-evaluation of the patient's vision and ocular status in the ensuing several days is advisable. ${ }^{32}$ The prophylactic use of antibiotics that cover against a broad range of infectious organisms is recommended. The prompt closure of an eye wall laceration would seem to be adequate to greatly reduce the risk of traumatic endophthalmitis. ${ }^{32}$ Additionally, corneal sutures in children attract blood vessels and scarring much more quickly than in adults. Sutures may need to be removed in a matter of weeks in young children. Failure to remove sutures may result in a completely vascularized cornea which impedes vision. ${ }^{32}$

Posterior lacerations almost always cut through the retina. Even so, the initial goal of surgery is wound closure. Most authorities do not use cryosurgery or scleral buckling at initial surgery. The trauma alone is enough to cause a retinal scar around a 
break. Management continues even after successful closure and repair of the wound. ${ }^{32}$

Surgical management of traumatic cataract consists of removal of a visually significant opaque lens. If a lens is removed at the same time that an eye wall laceration is closed, it may be safer to avoid simultaneous lens implantation but simultaneous corneal repair, lens aspiration, and posterior chamber lens implantation has its advocates. ${ }^{33}$ The reason for caution is that the implant could conceivably foster survival of bacterial organisms which penetrated the eye as a result of the trauma.

Without doubt, anterior lacerations carry a better prognosis than posterior lacerations. But in young children, with the risk of amblyopia, the prognosis may not be so good, even with anterior lacerations. When anterior lacerations are combined with cataract, the prognosis worsens. ${ }^{34}$ The prognosis also is highly dependent upon success in the management of amblyopia or the potential for amblyopia.

Hyphaema is the presence of red blood cells in the anterior chamber of the eye. Blunt or penetrating ocular trauma is a common cause. ${ }^{35}$ It was an indication for surgical intervention in 5(1.4\%) participants, of whom all 5(100\%) were male. This is comparable to a proportion of $86.7 \%$ reported by Uhumwangho in Benin City. ${ }^{36}$

\section{CONCLUSION}

We observed that most ocular traumas that required surgical intervention were preventable. A male child is twice more likely to have an ophthalmic surgical intervention due to trauma. The best form of management for ocular trauma is prevention.

\section{Recommendation}

We therefore recommend an extensive public enlightenment campaign that will focus on safety measures to prevent ocular injuries among children. It includes the following:

Encourage the wearing of suitable safety glasses or goggles by players who participate in games involving a small ball. ${ }^{37,38}$

Encourage parents and teachers to supervise play and sport when sharp objects (fencing, archery, etc) are used and teaching young people with respect to the use of handguns, air guns and all projectiles.

Emphasis must also be laid on the dangers associated with letting young children have unsupervised access to household implements such as nails, bottles, brooms, knives etc. Children must be discouraged from playing with stones, catapult, bottles, knives, sticks, pencils, biros, and all sharp toys.

Knowledge of where the injuries occur helps. ${ }^{39}$ Most injuries occur in the home, therefore parental education must be a priority. Furthermore, enforcing road safety rules and encouraging peaceful coexistence in the community will all help in preventing ocular injuries among children. Preventive, promotive and curative eye health services for the paediatric age group should be further strengthened.

\section{Conflict of interest}

None declared.

\section{REFERENCES}

1. Baker SP, O’Neill B, Karpf RS. The injury fact book. Lexington, MA, Lexington Books, 1984.

2. Abbott J, Shah P. The epidemiology and aetiology of pediatric ocular trauma. Surv Ophthalmol 2013;58(5):47685.

3. Minderhoud J, van Nispen RM, Heijthuijsen AA, Beunders VA, Mesquita-Voigt AT, Moll AC et al., Epidemiology and aetiology of childhood ocular trauma in the Republic of Suriname. Acta Ophthalmol 2016;94(5):479-484

4. Sundaram N. Ocular trauma an evolving sub specialty. Indian J Ophthalmol 2013; 61(10): 539-540.

5. Kanski JJ. Bowling B. Clinical Ophthalmology a systemic approach: Trauma 7th ed. Elsevier 2011:872-891.

6. Baxter RG, Hodgkins PR, Calder J, Morrell AJ, Vardy S, Elkington AR. Visual outcomes of childhood anterior perforating eye injuries: prognostic indications. Eye 1994;8:349-52.

7. Angra SK, Vajpayee RV, Titayal JS, Sharma YR, Sandramouli S, Kishore K. Types of posterior capsule breaks and their surgical management. Ophthalmic surg 1991;22:388-91.

8. Pant PR, Towner E, Pilkington P, Ellis M, Manandhar D. Community perception of unintentional child injuries in Makwanpur district of Nepal: a qualitative study. BMC Public Health 2014;14:476.

9. Cao H, Li L, Zhang M, Li H. Epidemiology of paediatric ocular trauma in the Chaoshan Region, China, 2001-2010. PLoS one 2013;8(4):e60844.doi10.1371/journal.pone.0060844

10. Ojabo CO, Malu KN, Adeniyi OS. Open globe injuries in Nigerian children: Epidemiological characteristics, 
etiological factors and visual outcome. Middle East Afr J Ophthalmol 2015;22(1):69-73.

11. Okeigbemen VW, Kayoma DH. Pattern of eye injuries in children in Benin city, Nigeria. Orient J Med 2013;25(1):19-23.

12. Adio AO, Nwachukwu H. Pattern of paediatric corneal laceration injuries in the University of Port Harcourt Teaching Hospital, Rivers State, Nigeria. BMC Research notes 2012;5:683. Published 2012 Dec 13 doi:10.1186/1756-0500-5-683.

13. Onyekonwu GC, Chuka-Okosa CM. Pattern and visual outcome of eye injuries in children at Abakaliki, Nigeria. West Afr J Med 2008;27:152-154.

14. Kyari F, Alhassan MB, Abiose A. Pattern and outcome of paediatric ocular trauma, a 3-year review of National Eye Centre Kaduna. Nig J Ophthalmol 2000;8:11-16.

15. Ukponmwan CU, Momoh RO. Broomstick injuries to the eye: an emerging cause of blindness among children in Nigeria. Niger J Surg 2015;21(1):13-17.

16. Onwasigwe EN, Umeh RE, Onwasigwe CN. Ocular injury in children. Nig J Ophthalmol 1994;2:9-12.

17. Khurana AK. Comprehensive Ophthalmology: Ocular injuries. 4th ed. New Age International Limited Publisher, New Delhi. (C2007;379.

18. El-Sebaity DM, Soliman W, Soliman AM, Fathalla AM. Eye injuries in upper Egypt. Clin Ophthalmol 2011;5:1417-1423.

19. Al-Mahdi HS, Bener A. Hashim SP. Clinical pattern of pediatric ocular trauma in fast developing country. IntEmergNurs 2011;19(4):184-191.

20. Liu ML, Chang YS, Tseng SH, Cheng HC,Huang FC, Shih MH et al. Major pediatric ocular trauma in Taiwan. J Pediatr Ophthalmol Strabismus 2010;47(2):88-95.

21. Grieshaber MC, Stegman R. Penetrating eye injuries in South African children: aetiology and visual outcome. Eye (Lond) 2006;20(7):789-795.

22. Saxena R, Sinha R, Purohit A, Dada T, Vajpayee RB, Azad RV. Pattern of paediatric ocular trauma in India. Indian J Pediatr 2002;69(10):863-867.

23. Thompson CG, Kumar N, Billson FA, Martin F. The aetiology of perforating ocular injuries in children. $\mathrm{Br} \mathrm{J}$ Ophthalmol 2002;86(8):920-922.

24. Niiranen M, Raivio I. Eye injuries in children. Br J Ophthalmol 1981;65:436-8.

25. Patel BC. Penetrating eye injuries. Arch Dis Child. 1989;64:317-20.
26. Bucan K, Matas A, Lovric JM, Batistic D, Borjan IP, Puljak L et al. Epidemiology of ocular trauma in children requiring hospital admission: a 16 year retrospective cohort study. J Glob Health 2017;7(1): 010415.

27. Ilsar M, Chirambo M, Belkin M. Ocular injuries in Malawi. Br J Ophthalmol 1982;66:145-8.

28. Murithi I, Gichuhi S, Njuguna MW. Ocular injuries in children. East Afr Med J 2008;85(1):39-45.

29. Alfaro DV, Chaudhry NA, Walonker AF, Runyan T, Salto Y, Liggett PPE. Penetrating eye injuries in young children. Retina 1994;14:201-5.

30. Cascairo M, Mazow M, Prager T. Paediatric ocular trauma: a retrospective survey. J Pediatr Ophthalmol Strabismus 1994;31:312-17.

31. Rudd J, Jaeger E, Freitag S, Jeffers J. Traumatically ruptured globes in children. J Pediatr Ophthalmol and Strabismus 1994;31:307-11.

32. Good WV. Accidental and non-accidental trauma: In: Paediatric Ophthalmology, Edited by David Taylor. 2nd ed. 1997; OBlackwell Science. Oxford 840-866.

33. Anwar M, Bleik J, von Noorden G, El-Maghraby A, Attia F. Posterior chamber lens implantation for primary repair of corneal lacerations and traumatic cataracts in children. J Pediatr Ophthalmol Strabismus 1994;31:157-61.

34. Baxter RJ, Hodgkins PR, Calder I, Morrell AJ, Vardy S, Elkington AR. Visual outcome of childhood anterior perforating eye injuries: prognostic indicators. Eye 1994;8:349-52.

35. Walton W, Von Hagen S, Grigorian R, Zarbin M. Management of traumatic hyphaema. Surv Ophthalmol 2002;47:297-334.

36. Uhumwangho OM, Umolo OC. Traumatic hyphaema in Benin City, Nigeria. Sahel Med J 2014;17:128-131.

37. www.preventblindness.org/preventing-eye-injuries.

38. Burton MJ. Corneal blindness: prevention, treatment and rehabilitation. Comm Eye Health J 2009;22(71):33-35.

39. Luff A, Hogdkins P, Baxter R, Morrell A, Calder I. Aetiology of perforating injury. Arch Dis Child 1993;68:682-3. 